\title{
Isolation and Identification of Pathogenic Bacteria from Vaginal Cavity of Sheep and Goats in Iraq
}

\author{
Safana Abdul Sattar Yaseen ${ }^{1}$ (D), Nabeel M.H. Al-Maaly ${ }^{2 *}$ (D) and \\ Ezdihar Mohammed Mahal Al-Rubaie ${ }^{1}$ (D) \\ ${ }^{1}$ Department of Microbiology, College of Veterinary Medicine, Baghdad University, Baghdad, Iraq. ${ }^{2}$ Department \\ of Internal and Preventive Medicine, College of Veterinary Medicine, Baghdad University, Iraq.
}

\begin{abstract}
This study intends to explore the prevalence of pathogenic bacteria infected the vaginal cavity of sheep and goats, in addition to determine the normal vaginal bacterial flora in pregnant and non pregnant local breed goat and sheep. Vaginal swabs were collected from 80 cases comprised of 54 sheep and 26 goats that involve 20 and 6 pregnant ewes and goats from Baghdad city during May 2019 to July 2019. These samples were cultivated onto different bacteriological media. The isolated bacteria were identified by different biochemical tests. Mixed bacterial isolates were determined in 65 out of $80(81.3 \%)$ samples. Totally, 9 various microorganisms were isolated from animal's vagina. E. coli, Streptococcus Spp, KlebsiellaSpp and Staphylococcus aureus were the most common isolated microorganism from vaginal swabs in a percentage of 36, 20, 17.5 and $16.3 \%$ respectively. While Bacillus Spp, Proteus Spp, Staphylococcus Spp, Corynebacterium Spp and Salmonella Spp. were the less common isolated microorganisms in a percentages of 10, 10, 7.5, 6.3 and \%2.5 respectively. Moreover, the enteric bacteria especially $E$. coli was isolated in the higher incidence rate $(44.4 \%)$ in pregnant ewes compared to pregnant goats $\mathbf{1 5 . 4 \%}$. However, in non-pregnant animals, the percentages were 50 and $15 \%$ in sheep and goats respectively. Nonetheless, Proteus Spp were isolated only from newly birth animals. Meanwhile, Staphylococcus aureus were relatively isolated the same level of incidence at $15 \%-17 \%$ in either pregnant or non-pregnant sheep or goats, while Streptococcus Spp were mostly found in pregnant goats and ewes at 50 and $25 \%$ respectively. In conclusion, this study approved the isolation of different bacterial spp in various incidence rates from vaginal cavity of pregnant and nonpregnant sheep and goats.
\end{abstract}

Keywords: Pathogenic bacteria, bacterial flora, vaginal cavity, sheep and goats, vaginal swabs.

*Correspondence: ezn_2006@yahoo.com

(Received: 08 September 2019; accepted: 04 November 2019)

Citation: Safana Abdul Sattar Yaseen, Nabeel M.H. Al-Maaly and Ezdihar Mohammed Mahal Al-Rubaie, Isolation and Identification of Pathogenic Bacteria from Vaginal Cavity of Sheep and Goats in Iraq, J Pure Appl Microbiol., 2019; 13(4):2295-2299. https:// doi.org/10.22207/JPAM.13.4.44

(C) The Author(s) 2019. Open Access. This article is distributed under the terms of the Creative Commons Attribution 4.0 International License which permits unrestricted use, sharing, distribution, and reproduction in any medium, provided you give appropriate credit to the original author(s) and the source, provide a link to the Creative Commons license, and indicate if changes were made. 


\section{INTRODUCTION}

The importance of reproductive efficiency in the sheep is very essential because of the seasonal breeding. Many diseases are classified as specific and non-specific which cause problems in the reproductive system in the sheep. Some of these diseases cause infertility or reduce productivity with clinical signs which may include vaginal discharge. Abortion and infertility can result from infection or from non-infectious causes (El-Arabi et al., 2013).

Genital infections in domestic ruminants are often caused by opportunistic secondary invaders, especially Escherichia coli spp that have frequently been isolated in majority from ewes (Sargison et al., 2007 and Manes et al., 2010), goats (Ababneh and Degefa, 2006). Coliforms (of fecal origin) and other non-specific bacteria are also opportunistic pathogens in the reproductive tract. Under stressful conditions, these opportunist bacteria may cause genital infection that usually leads to reproductive failure in ruminants (Shallali et al., 2001 and Mshelia et al., 2014).Vaginitis, a common disease of the genital tract of domestic ruminants, is often caused by secondary bacterial invaders, mainly the $E$. coli species(Sargison et al., 2007 and Manes et al., 2010).

These microorganisms caused diseases due to stress and reduction of the immunity of the reproductive system (Al-Dahash and Fathalla 2000). Mavrogianni et al. (2007) found bacteria in the uterus of ewes after lambing and found E.coli, Apyogenes, Staphylococci and Streptococci after interference. El-Arabi et al. (2013) isolated normal bacterial flora of vaginal cavity in normal sheep. Vasconcelos et al. (2016) reported that sheep treated with either sponges or intravaginal implant containing progesterone (CIDR) have a high prevalence of $E$. coli, probably of fecal source, which are opportunistic agents of bacterial vaginitis. Staphylococcus aureus is considered an inhabitant of vulva and vagina and identified as the most common causative agent of purulent vaginitis in ewes (Donders et al.,2002 and Braganna et al.,2017). Manes et al. (2010) isolated Bacillus spp., Corynebacterium spp., Escherichia spp., Staphylococcus spp., and Streptococcus spp. from the ewe's vagina.

\section{MATERIAL AND METHODS \\ Collection of samples}

For bacterial isolation, 80 vaginal swabs were collected aseptically from 54 sheep and 26 goats from different areas in Baghdad city. All samples were collected using disposable sterile swabs with transport media (Greiner). The out surface of vagina was disinfected by $70 \%$ alcohol then the swabs were introduced in vaginal cavities to collect the samples. These swab samples were cultured on different cultural media and incubated at $37^{\circ} \mathrm{C}$ for $24-48 \mathrm{hrs}$. All bacterial isolates were identified by cultural characteristic features of colonies on primary and specific media in addition to gram staining and according to the results of biochemical tests. (Quinn et al., 2004).

\section{Cultural media}

Different cultural media were used to cultivate the samples including blood agar, MacConky agar, Mannitol salt agar, Eosin Methylene Blue agar, nutrient agar, tetrathionate broth and SS agar and incubated at $37^{\circ} \mathrm{C}$ for $24-48$ hrs.

\section{Biochemical tests}

Many different biochemical tests were done to identify the bacterial isolates including catalase test, coagulase test, IMVIC test, TSI test and motility test.

\section{RESULT AND DISCUSSION}

In this study, the results were revealed that nine bacterial isolates were identified in various percentages in sheep and goats. The isolated microorganisms are including E.coli; Staphylococcusaureus; Staphylococcus spp; Salmonella spp; Streptococcusspp; Proteus spp; Bacillus spp; Klebsiellaspp and Corynebacterium spp. ( Table 1). These results agree with previous researchers Manes et al., 2010 and Al-Zubaidi et al., 2013. These researchers approved the isolation of many bacteria from vaginal cavity of sheep and goats and found the impact factors of the isolated bacteria on the occurrence of infertility and problems of the reproductive system. Moreover, Al-Delemi (2005) stated that several bacterial types presented in the female genital system. Meanwhile, Zaid, (2009) reported the isolation of 12 different types of bacteria from the reproductive tract and approved the probability 
of presence of more than one type of bacteria in the same swabs. However, many studies shown that these bacteria were normal residents of the anterior vagina in does and ewes (Bukar-Koloet al.,2007; Mshelia et al., 2014).

E.coli was the first dominant bacteria in ewes and goats and occurred at $44.4 \%$ and $15.4 \%$ respectively, moreover, Klebsiella was isolated as a second dominant bacterium.

These results agree with previous reresearch (Al-Hilli and Ajeel, 2015), who stated that E.coli was the dominant isolates from vaginal swabs of ewes and Klebsiella was the second dominant. Additionally, El-Arabi et al., (2013) mentioned that E.coli and Streptococcus spp were the predominant bacteria.

The results of the current study revealed the isolation of different percentages of microorganisms in pregnant and non-pregnant ewes and does table ( $2 \& 3$ ). These results are compatible with other researcher (Martins et al., 2009), who stated that the alteration on microflora was due to changes of vaginal environment such as $\mathrm{pH}$ modifications during estrus and pregnancy.

The presence of these microorganisms in the vagina as we isolated in this study may cause bacterial vaginitis following the exposure to any factors causing depression of the immunity system

Table 1. The percentage of bacterial isolates from vaginal swabs of sheep and goats

\begin{tabular}{|c|c|c|c|c|c|c|}
\hline \multirow{2}{*}{$\begin{array}{l}\text { Bacterial isolates } \\
\text { (nine isolates) } \\
\text { from vaginal cavity } \\
\text { E.coli }\end{array}$} & \multicolumn{2}{|c|}{$\begin{array}{c}\text { Sheep } \\
\text { No. of isolates } \\
\text { out of } \\
\text { (54 samples) } \\
\text { (\%) }\end{array}$} & \multicolumn{2}{|c|}{$\begin{array}{c}\text { Goat } \\
\text { No. of isolates } \\
\text { out of } \\
\text { (26 samples) } \\
(\%)\end{array}$} & \multicolumn{2}{|c|}{$\begin{array}{l}\text { Total no. of } \\
\text { isolates } \\
\text { out of } \\
\text { (80 sample) } \\
(\%)\end{array}$} \\
\hline & 24 & $44.40 \%$ & 4 & $15.40 \%$ & 28 & $35 \%$ \\
\hline Staphylococcus aureus & 9 & $16.60 \%$ & 4 & $15.40 \%$ & 13 & 16.3 \\
\hline Staphylococcus spp & 2 & $3.70 \%$ & 4 & $15.40 \%$ & 6 & $7.50 \%$ \\
\hline Salmonella spp. & 1 & $1.90 \%$ & 1 & $3.80 \%$ & 2 & $2.50 \%$ \\
\hline Streptococcus Spp. & 6 & $11.10 \%$ & 10 & $38.50 \%$ & 1 & $620 \%$ \\
\hline Proteus spp & 3 & $5.60 \%$ & 5 & $19.20 \%$ & 8 & $10 \%$ \\
\hline Bacillus spp & 3 & $5.60 \%$ & 5 & $19.20 \%$ & 8 & $10 \%$ \\
\hline Klebsiella spp. & 10 & $18.50 \%$ & 4 & $15.40 \%$ & 14 & $17.50 \%$ \\
\hline Corynebacterium spp & 3 & $5.60 \%$ & 2 & $7.70 \%$ & 5 & $6.25 \%$ \\
\hline No growth & 10 & $18.50 \%$ & 5 & $19.20 \%$ & 15 & $18.80 \%$ \\
\hline
\end{tabular}

Table 2. The percentage of bacterial isolates from vaginal swabs of pregnant and non- pregnant ewes

\begin{tabular}{|c|c|c|c|c|c|c|}
\hline \multirow{3}{*}{$\begin{array}{l}\text { Bacterial isolate } \\
\text { (nine isolates)from } \\
\text { vaginal cavity } \\
\text { E.coli }\end{array}$} & \multicolumn{4}{|c|}{$\begin{array}{l}\text { Sheep } \\
\text { No. of isolates out of }\end{array}$} & \multirow{2}{*}{\multicolumn{2}{|c|}{$\begin{array}{c}\text { Total no. of isolates } \\
\text { out of } \\
\text { (54 samples)(\%) }\end{array}$}} \\
\hline & \multicolumn{2}{|c|}{$\begin{array}{c}\text { Pregnant } \\
\text { (20) samples\% }\end{array}$} & \multicolumn{2}{|c|}{$\begin{array}{l}\text { Non-Pregnant } \\
\text { (34) samples\% }\end{array}$} & & \\
\hline & 7 & $\% 35$ & 17 & $\% 50$ & 24 & $\% 44.4$ \\
\hline Staphylococcus aureus & 3 & $\% 15$ & 6 & $\% 17.6$ & 9 & \%16.6 \\
\hline Staphylococcus spp & 1 & $\% 5$ & 1 & $\% 2.9$ & 2 & $\% 3.7$ \\
\hline Salmonella spp. & _ & . & 1 & $\% 2.9$ & 1 & $\% 1.9$ \\
\hline Streptococcus Spp. & $\overline{5}$ & $\% 25$ & 1 & $\% 2.9$ & 6 & $\% 11.1$ \\
\hline Proteus spp & - & . & 3 & $\% 8.8$ & 3 & $\% 5.6$ \\
\hline Bacillus spp & - & . & 3 & $\% 8.8$ & 3 & $\% 5.6$ \\
\hline Klebsiella spp. & 2 & $\% 10$ & 8 & $\% 23.5$ & 10 & $\% 18.5$ \\
\hline Corynebacterium spp & _ & . & 3 & $\% 8.8$ & 3 & $\% 5.6$ \\
\hline No growth & $\overline{5}$ & $\% 25$ & 5 & 14.7 & 10 & $\% 18.5$ \\
\hline
\end{tabular}


Table 3. The percentage of bacterial isolates from vaginal swabs of pregnant and non- pregnant does

\begin{tabular}{|c|c|c|c|c|c|c|}
\hline \multirow{4}{*}{$\begin{array}{l}\text { Bacterial isolate } \\
\text { (nine isolates) from } \\
\text { vaginal cavity } \\
\text { E.coli }\end{array}$} & \multirow{2}{*}{\multicolumn{4}{|c|}{$\begin{array}{l}\text { goats } \\
\text { No. of isolates out of }\end{array}$}} & \multirow{3}{*}{\multicolumn{2}{|c|}{$\begin{array}{l}\text { Total no. of isolates } \\
\text { out of (26samples) } \\
\text { (\%) }\end{array}$}} \\
\hline & & & & & & \\
\hline & \multicolumn{2}{|c|}{$\begin{array}{c}\text { Pregnant } \\
\text { (6) samples \% }\end{array}$} & \multicolumn{2}{|c|}{$\begin{array}{l}\text { Non -Pregnant } \\
\text { (20) samples \% }\end{array}$} & & \\
\hline & 1 & $16.70 \%$ & 3 & $15 \%$ & 4 & $15.40 \%$ \\
\hline Staphylococcus aureus & 1 & $16.70 \%$ & 3 & $15 \%$ & 4 & $15.40 \%$ \\
\hline Staphylococcus spp & 2 & $33.30 \%$ & 2 & $10 \%$ & 4 & $15.40 \%$ \\
\hline Salmonella spp. & - & . & 1 & $5 \%$ & 1 & $3.80 \%$ \\
\hline Streptococcus spp. & 3 & $50 \%$ & 7 & $35 \%$ & 10 & $38.50 \%$ \\
\hline Proteus spp & - & . & 5 & $25 \%$ & 5 & $19.20 \%$ \\
\hline Bacillus spp & - & . & 5 & $25 \%$ & 5 & $19.20 \%$ \\
\hline Klebsiella spp. & - & . & 4 & $20 \%$ & 4 & $15.40 \%$ \\
\hline Corynebacterium spp & _ & . & 2 & $10 \%$ & 2 & $7.70 \%$ \\
\hline No growth & $\overline{1}$ & $16.70 \%$ & 4 & $20 \%$ & 5 & $19.20 \%$ \\
\hline
\end{tabular}

of the animals and affect the fertility status and this idea also mentioned by Bukar et al., (2007).

In conclusion, this study approved the isolation of different bacterial spp in various incidence rates from vaginal cavity of pregnant and non-pregnant sheep and goats. Totally, 9 various microorganisms were isolated from animals vagina. According to our conclusion we recommended to follow hygienic precautions in intra vaginal implantation to minimize the contamination and avoid the infection with secondary bacterial invaders in addition to reduce the chance of infertility.

\section{ACKNOWLEDGEMENTS}

None.

\section{CONFLICTS OF INTEREST}

The authors declare that there is no conflict of interest.

\section{AUTHORS' CONTRIBUTION}

All authors listed have made a substantial direct and intellectual contribution to the work, and approved it for publication.

\section{FUNDING}

None.

\section{DATA AVAILABILITY}

All datasets generated or analyzed during this study are included in the manuscript and/or the Supplementary Files.

\section{ETHICS STATEMENT}

This article does not contain any studies with human participants or animals performed by any of the authors.

\section{REFERENCES}

1. Ababneh M.M. and Degefa, T. Bacteriological findings and hormonal profile in the postpartum Balady goats. Reproduction in Domestic Animals, 2006; 41(1): 12 -16. https://doi.org/10.1111/j.1439-0531.2006.00638.x

2. Al- Hilli Z.B. and Ajeel H.H. Isolation and Identification of Bacterial Flora from Vagina in Normal Ewes (Slaughter and Living Ewes). (IOSR-JPBS), 2015; 10(6): 01-04.

3. Al-Delemi, D.H.J. The normal bacterial flora in the vaginal cavity of Iraqi cows, sheep, goats and camels during the luteal phase. Al-Qadisiya J. Vet. Med. Sci., 2005; 4(1): 23-29.

4. Al-Zubaidi, S.F.; Hasson, S.O., and Ajeel, H.H. Isolation and identification of microflora species at different levels of the ewe genital tract. J. Agric. Vet. Sci., 2013; 6: 54-57. https://doi.org/10.9790/2380-0635457

5. Braganca J.F.M.; Maciel J.M.; Girardini L.K.; Machado S.A.; da Rocha J.F.X.; Tonin A.A. and da Rocha R.X. Influence of a device intravaginal to synchronization/ induction of estrus and its reuse in sheep vaginal flora. Comp. Clin. Pathol., 2017; 26: 1369-1373. https://doi.org/10.1007/s00580-017-2542-z

Bukar-Kolo, Y.M.; Amin, J.D. and Zaria, L.T. Bacterial flora of the anterior genitalia of Sahelian doe in Maiduguri- Borno state, Nigeria. Nig. Vet. J., 2007; 28: 60- 62. https://doi.org/10.4314/nvj.v28i2.3558

7. Donders G.G.G.; Vereecken A.; Bosmans E.; Dekeersmaecker A.; Salembier G. And Spitz B. 
Definition of a type of abnormal vaginal flora that is distinct from bacterial vaginosis: Aerobic vaginitis. $\mathrm{Br}$. J. Obstetr. Gynecol., 2002; 109: 34-43. https://doi. org/10.1111/j.1471-0528.2002.00432.x

8. $\quad$ El-Arabi A.A.; Taylor D.J.; Logue D.N. and Benothman M. Isolation and Identification of Bacterial Flora from Reproductive Tracts of Normal Ewes in Glasgow. J. Vet. Adv., 2013; 3(10): 275-280.

9. Manes, J.; Fiorentino, M.A.; Kaiser, G.; Hozbor, F.; Alberio, R.; Sanchez, E. and Paolicchi, F. Changes in the aerobic vaginal flora after treatment with different intravaginal devices in ewes. Small Ruminant Research, 2010; 94(1-3): 201-204. https://doi.org/10.1016/j. smallrumres.2010.07.021

10. Martins, G.; Figueira, L.; Penna, B.; Brandao, F.; Varges, R.; Vasconcelos, C. and Lilenbaum, W. Prevalence and antimicrobial susceptibility of vaginal bacteria from ewes treated with progestin-impregnated intravaginal sponges. Small Ruminant Research, 2009; 81(2): 182-184. https://doi.org/10.1016/j. smallrumres.2008.12.003

11. Mshelia, V.T.; Maina, V.A.; Okon, K.; Mamza, S.A.; Peter, I.D. and Egwu, G.O. Microbiological studies on genital infections in slaughtered ewes from tropical arid zone of Nigeria. Sokoto Journal of Veterinary Sciences. J. Veterinary Sciences, 2014; 12(1): 18-22. https://doi. org/10.4314/sokjvs.v12i1.3
12. Mavrogianni V.S.; Amiridis G.S.; Gougoulis D.A.; Fragkou I. A. and Fthenakis G.C. Efficacy of difloxacin for the control of postpartum uterine infections of ewes. J. Vet. Pharmacol. Therapeut., 2007; 30: 583-585. https://doi.org/10.1111/j.1365-2885.2007.00903.x

13. Quinn, P.J.; Carter, M.E.; Markey, B. and Carter, G.R. Clinical Veterinary Microbiology. $6^{\text {th }}$ ed. Mosby ANIMP Wolf, London, 2004; $13-17$.

14. Sargison, N.D.; Howie, F.; Mearns, R.; Penny, C. D.; and Foster, G. Shiga toxin-producing Escherichia coli as a perennial cause of abortion in a closed flock of Suffolk ewes. Veterinary Record, 2007; 160(25): 875-876. https://doi.org/10.1136/vr.160.25.875

15. Shallali, A.A.; Hussein, A.M.; Salih, M.M.; and Dafalla, E.A. A preliminary report on bacteria isolated from the female genital tract of sudanese sheep and goats. The Sudan Journal of Veterinary Research, 2001; 17(1): 55-63.

16. Vasconcelos C.; BrandTo F.Z.; Martins G.; Penna B.; Souza J.M.G. and Lilenbaum W. Qualitative and quantitative analysis of bacteria from vaginitis associated with intravaginal implants in ewes following estrus synchronization. Ciencia Rural, 2016; 46: 632636. https://doi.org/10.1590/0103-8478cr20150365

17. Zaid, N.W. Vaginal flora of Iraqi sheep and goats during different reproductive stages. Al-Anbar J. Vet. Sci., 2009; 2(1): 25-30. 